\title{
Bond Strength and Cytotoxicity of a Universal Adhesive According to the Hybridization Strategies to Dentin
}

\author{
Maria Luísa de Alencar e Silva Leite ${ }^{1}$, Carlos Alberto de Souza Costa ${ }^{2}$, \\ Rosângela Marques Duarte ${ }^{3}$, Ana Karina Maciel de Andrade ${ }^{3}$, Diana Gabriela \\ Soares ${ }^{2}$
}

'Department of Dental Materials and Prosthodontics, UNESP Universidade Estadual Paulista, Araraquara, SP, Brazil

${ }^{2}$ Department of Physiology and Pathology, UNESP Universidade Estadual Paulista, Araraquara, SP, Brazil

${ }^{3}$ Department of Restorative Dentistry, UFPB - Universidade Federal da Paraíba, João Pessoa, PB, Brazil

Correspondence: Diana Gabriela Soares, Rua Humaitá, 1680, CEP: 14801-903 Araraquara, SP, Brazil. Tel: +55-16-3301-6477. e-mail: diana_odonto@yahoo.com.br

Key Words: bond strength, cytotoxicity, adhesive system, pulp cell.

\section{Introduction}

Hybridization of dentin may be influenced by several factors, including the composition of and application protocols for adhesive systems to dentin surfaces, as well as the inherent characteristics of dentin substrate (1). Adhesive systems have been classified into two major categories: etch-and-rinse and self-etch systems (2). The ER technique involves dentin demineralization with phosphoric acid to expose collagen fibrils for resin infiltration. However, incomplete filling of demineralized dentin by resin monomers is observed following the ER protocol, due to the hydrophobic nature of resin monomers. Thus, areas of incomplete monomeric infiltration remain at the dentinresin interface (3). Nevertheless, dentin etching increases permeability and hydraulic conductance at the pulpal wall upon removal of the smear layer and the opening of dentinal tubules (4). This high humidity interferes with the polymerization of adhesive systems, enhancing the local presence of toxic unreacted free monomers (2), which are capable of diffusing through dentin to cause pulp tissue damage (5).

The application of adhesive systems to dry dentin following the SE strategy has been considered a very promising protocol, since monomeric phase separation and hydrolytic degradation could be partially minimized (6). These systems claim to possess better biological behavior, since the smear layer is not removed, thus reducing the transdentinal diffusion of uncured resin monomers (2). During SE bonding, dissolved hydroxyapatite crystals are incorporated into the hybridized complex, and, depending on the $\mathrm{pH}$ of the adhesive system, the whole extension of demineralized dentin is impregnated by resin monomers (2). For this reason, the SE strategy has not been considered highly sensitive to moisture and drying (7). However, although the number of clinical steps is reduced with SE systems, the longevity of the restoration may be compromised compared with that produced by ER systems, especially when simplified versions of these adhesives (one-step systems) are used (8).

A new category of dentin adhesives, called "universal" or "multi-mode" adhesives, has been considered versatile, since both self-etching and etch-and-rinse strategies could be applied to wet or dry dentin (1). The acquisition of lasting and stable adhesion in demineralized dry dentin can open a new perspective on adhesive dentistry, since the degree of moist dentin capable of avoiding the risk of collagen fibril collapse is difficult to standardize in daily clinical 
practice. Also, phase separation and hydrolytic degradation phenomena seem to be minimized (6).

Besides the high-quality dentin bond that is the goal of current adhesive dentistry, a concern regarding these dental materials is related to their biocompatibility with the pulp-dentin complex, especially when they are applied to deep dentin (5). The capability of residual monomers to elicit toxic reactions in pulp tissue is directly related to dentin permeability and humidity. Next to the pulp chamber, the diameter and number of dentinal tubules per area increase, resulting in high permeability (5). This permeable substrate features a large quantity of dentinal fluid, which may interfere with the polymerization of resin materials enhancing the local presence of toxic unreacted free monomers $(2,9)$. Therefore, since chemical composition of dental materials as well as the protocols of application to dentin play a central role in defining their mechanical behavior and compatibility with the pulp-dentin complex $(2,5,10)$, the objective of this study was to evaluate the microtensile bond strength ( $\mu \mathrm{TBS}$ ) and transdentinal cytotoxicity of a universal adhesive system according to the hybridization strategies to dentin. The null hypothesis was that neither dentin wettability nor application protocol would influence the mechanical and biological behavior of the Scotchbond ${ }^{\mathrm{TM}}$ Universal (3M ESPE) adhesive system.

\section{Material and Methods}

\section{Microtensile Bond Strength ( $\mu$ TBS)}

After approval by the Ethics Committee in Research of the Health Sciences Center of the Federal University of Paraiba, Brazil (Process \# 17665613.2.0000.5188), 30 healthy human third molars were obtained, cleaned and embedded in acrylic resin cylinders. The occlusal enamel was removed by means of a diamond disc (Extec; Enfield, CT, USA) mounted on a metallographic cutter (Labcut 1010, Extec Corp., London, UK) under watercooling. Then, the samples were ground wet with 600 -grit abrasive papers (Carborundum Abrasives; Recife, PE, Brazil) coupled to a polishing machine (Erios - 27000; São Paulo, $\mathrm{SP}$, Brazil) at $300 \mathrm{rpm}$ for $60 \mathrm{~s}$, to provide a homogeneous smear layer. The following groups were stablished $(n=5)$ according to the adhesive system and application protocol on dentin surface: SU:ER/wet - Scotchbond Universal ${ }^{\mathrm{TM}}$ (SU; 3M ESPE, St. Paul, MN, USA), applied on wet dentin following etch-and-rinse protocol; SU:ER/dry-SU adhesive applied on dry dentin following etch-and-rinse protocol; SU:SE/wet - SU adhesive applied on wet dentin following self-etching protocol; SU:SE/dry - SU adhesive applied on dry dentin following self-etching protocol; ASB:ER/PC Adper Single Bond 2 ${ }^{\mathrm{TM}}$ (ASB; 3M ESPE, St. Paul, MN, USA), an etch-and-rinse adhesive system used as etch-and-rinse positive control; CSB:SE/PC. Clearfil SE Bond ${ }^{\mathrm{TM}}$ (CSB; Kuraray
Co. Ltd., Osaka, Japan), a self-etching adhesive system was used as self-etching positive control. Detailed information on the chemical compositions and application protocols of the adhesive systems is given in Table 1.

A 4.5-mm-high resin composite block (Z100; 3M ESPE, St. Paul, MN, USA) was built up incrementally, and each increment $(1.5 \mathrm{~mm})$ was light-cured for $40 \mathrm{~s}$ by means of

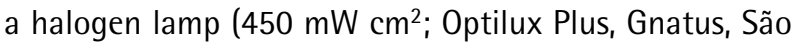
Paulo, SP, Brazil). The restored teeth were then stored in deionized water and kept in an incubator at $37{ }^{\circ} \mathrm{C}$ for 24 h. Thereafter, dentin beams $1 \mathrm{~mm}$ in width, $1 \mathrm{~mm}$ in depth and $10 \mathrm{~mm}$ in height were obtained via a high-precision cutting machine (Labcut 1010; Extec, Enfield, CT, USA) equipped with a diamond disc (Extec). Each tooth yielded 15 beams, which were then tested $24 \mathrm{~h}$ after the bonding procedures. The cross-sectional area of each beam was individually measured (Model 500-144B; Mitutoyo South America Ltda., Suzano, SP, Brazil), then fixed to a testing device with cyanoacrylate glue (Super Bonder Gel; Henkel Loctite, São Paulo, SP, Brazil) and subjected to the $\mu$ TBS test in a mechanical testing machine (Microtensor OM100; Odeme, Lucerne, SC, Brazil), equipped with a $500 \mathrm{~N}$ load cell running at a crosshead speed of $5 \mathrm{~mm} / \mathrm{min}$. The $\mu$ TBS data, expressed in megapascals (MPa), were recorded, being obtained by division of the force applied at the time of break over the union area $\left(\mathrm{mm}^{2}\right)$. Then, the data were tabulated and submitted to the Shapiro-Wilk test. Given the normal distribution of the data, one-way ANOVA and Tukey tests were applied considering a significance level of $5 \%$. After the test, the fractured beams were examined under an inverted optical microscope (XJM-400 series; KOZO, Nanjing, China) at 100X magnification, and failures were classified as follows: Type I - cohesive fracture in the adhesive; Type II - cohesive fracture in the dentin; Type III - cohesive fracture in the hybrid layer; and Type IV - mixed fracture: cohesive in the adhesive and in the hybrid layer.

\section{Transdentinal Cytotoxicity} Preparation of Dentin Discs

Dentin discs ( $0.4 \mathrm{~mm}$ thick; $\mathrm{n}=56$ ) were obtained from healthy human third molars(Process\#32272114.9.0000.5188; Ethics Committee in Research of the Health Sciences Center of the Federal University of Paraiba, Brazil), as described in detail by Soares et al. (11). The discs were ground wet with 400- and 600-grit abrasive papers (Carborundum Abrasives, Recife, PE, Brazil) to a set thickness at $0.4 \mathrm{~mm}$, measured by digital caliper (Model 500-144B; Mitutoyo South America Ltda., Suzano, SP, Brazil). Then, a $0.5 \mathrm{~mol} / \mathrm{L}$ EDTA solution was applied to each surface for $60 \mathrm{~s}$ to remove the smear layer, followed by washing in deionized water for the same period (11). The discs were adapted to a filtration chamber, and a cannula was connected to a $1.80-\mathrm{m}$ column of water 
through a $0.5-\mathrm{mm}$-diameter polyethylene tube. The dentin disc remained under this pressure ( $\mathrm{cm} \mathrm{H}_{2} \mathrm{O}$ ) for $5 \mathrm{~min}$, and the time required for microbubble movement through the cannula was recorded for $1 \mathrm{~min}$. The hydraulic conductance values of each disc were obtained by the formula $L p=J v / A . \Delta$ P.t, where " $\mathrm{Lp}$ " is the hydraulic conductance $(\mu \mathrm{L}$ $\left.\mathrm{cm}^{-2} \mathrm{~min}^{-1} \mathrm{~cm} \mathrm{H}_{2} \mathrm{O}^{-1}\right)$, "Jv" is the volume of fluid in $\mu \mathrm{L} / \mathrm{mm}$, "A" is the dentin surface area $\left(\mathrm{cm}^{2}\right), " \Delta \mathrm{P}$ " is the hydrostatic pressure in $\mathrm{cm}_{2} \mathrm{O}$ and " $\mathrm{t}$ " is the time required for fluid movement (min). After hydraulic conductance analysis, the discs were randomly assigned to the experimental groups in such a way that the statistical analysis of the hydraulic conductance values presented similar dentin permeability among groups (one-way ANOVA, $p>0.05$ ). This procedure was carried out to standardize the permeability of the discs distributed among groups, since dentin hydraulic conductance plays a role in the diffusion of resin monomers through dentin $(4,11)$.

The same experimental groups described in Table 1 were established. A negative control (NC) group, in which no treatment was performed on dentin surfaces, was also established, to represent normal cell parameters.

\section{Artificial Pulp Chamber (APC)}

The diameters of the dentin discs were reduced to $8 \mathrm{~mm}$ by means of a cylindrical diamond bur (\#1095 - KG Sorensen, Barueri, $S P$, Brazil). Then, the occlusal surface of each disc was ground for $10 \mathrm{~s}$ with 600-grit abrasive papers (Carborundum Abrasives, Recife, PE, Brazil) to obtain a homogeneous smear layer (12). The artificial pulp chamber (APC; Fig. 1) employed in this investigation has also been used by other researchers $(4,11)$. Each dentin disc was individually placed in the upper compartment, between two silicon rings (Rodimar Rolamentos Ltda, Araraquara, SP, Brazil), with the pulp surface facing down and the occlusal surface facing up. The APC/disc sets were sterilized with ethylene oxide.

MDPC-23 Cell Culture in Dentin Discs

Odontoblast-like MDPC-23 cells were

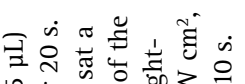

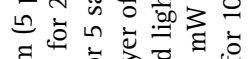

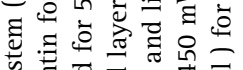

के

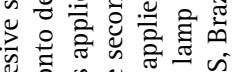

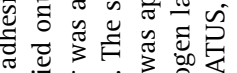

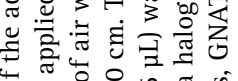

낭

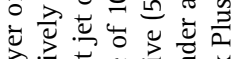

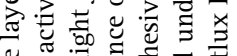

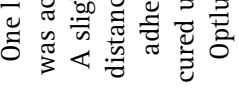

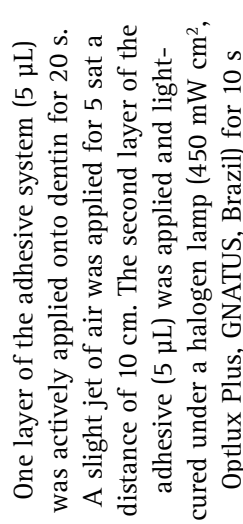

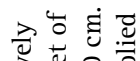

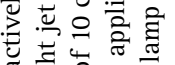

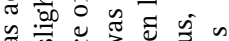

气 to

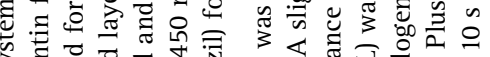

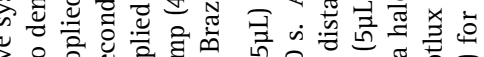

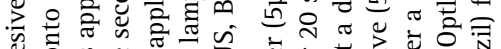

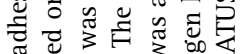

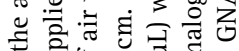

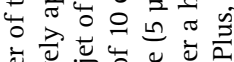

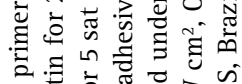

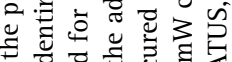

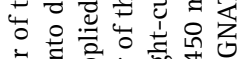

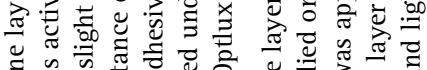

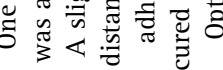

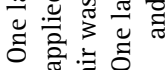
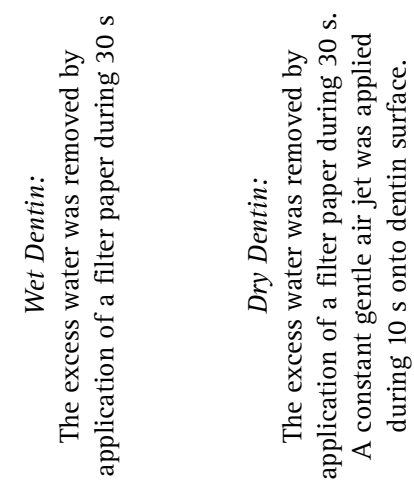

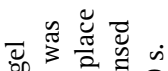
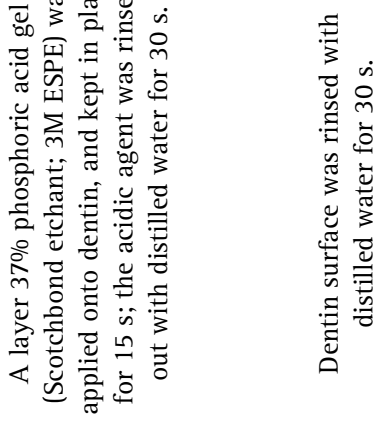

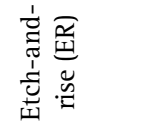

岕总焉

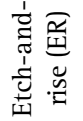
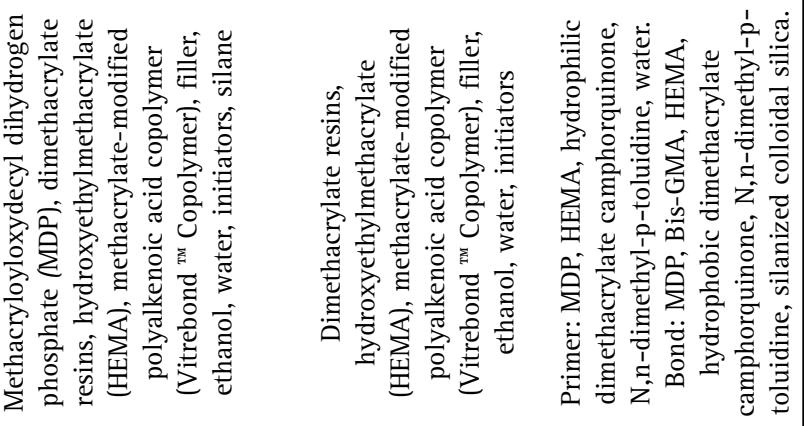

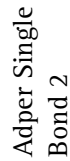

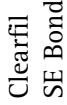


cultivated in Dulbecco's Modified Eagle's Medium (DMEM plus $100 \mathrm{IU} / \mathrm{mL}$ penicillin, $100 \mu \mathrm{g} / \mathrm{mL}$ streptomycin and $2 \mathrm{mmol} / \mathrm{L}$ glutamine; Gibco, Grand Island, NY, USA) supplemented with 10\% fetal bovine serum (FBS; Gibco). The APC/disc sets were placed on 24-well plates (Corning Incorporated; Corning, NY, USA) with the pulpal side of dentin facing upward. In total, $3 \times 10^{4}$ cells in a $20-\mu \mathrm{L}$ volume were seeded onto the pulpal side of dentin, and the sets were maintained in an incubator with $5 \% \mathrm{CO}_{2}$ at $37^{\circ} \mathrm{C}$ for $30 \mathrm{~min}$ to allow initial cell adhesion. Then, $1 \mathrm{~mL}$ of complete DMEM was added to the APC/disc sets and incubated for an additional 48-hour period, allowing the pulp cells to spread and proliferate on dentin substrate (12).

\section{Experimental Design}

Following the 48-h incubation time, the culture medium was replaced by $1 \mathrm{~mL}$ of DMEM with no FBS, and the APCs were placed with the occlusal sides of the discs turned upward such that the pulp surface was maintained in direct contact with DMEM, and the occlusal surface remained exposed to receive the adhesive procedures (11). The same protocols described in Table 1 were performed for the experimental groups $(\mathrm{n}=8)$. The negative control group (NC) received no treatment on occlusal dentin surfaces. After that, the APC/disc sets were incubated with $5 \% \mathrm{CO}_{2}$ at $37{ }^{\circ} \mathrm{C}$ for $24 \mathrm{~h}$, then for $4 \mathrm{~h}$ with $1 \mathrm{~mL}$ of Alamar Blue solution (Life Technologies, Grand Island, NY, USA) in DMEM (1:10) for cell viability measurement. After this period, the supernatant was transferred to 96 -well plates and analyzed with a fluorescence reader (excitation $540 \mathrm{~nm}$; emission $590 \mathrm{~nm}$ ) (Synergy H1; BioTek, Winooski, VT, USA). The NC group was considered as having 100\% cell viability. The data were also submitted to the Shapiro-Wilk test to evaluate the normal distribution of the data, followed by one-way ANOVA and Tukey tests $(\alpha=5 \%)$. At the end of cell viability testing, two dentin discs of each group were removed from APCs for evaluation of cell morphology by scanning electron microscopy (SEM). For this, the cells were fixed with 2.5\% glutaraldehyde, washed with phosphate-buffered saline (PBS) and post-fixed with 1\% osmium tetroxide, followed by dehydration in an ascending series of water-ethanol solutions (30\%, 50\%, 70\%, 95\% and 100\%). In sequence, the specimens were chemically dried in $\operatorname{HMDS}(1,1,1,3,3$, 3 hexamethyldisilazane). Then, the dentin discs were placed on metallic stubs and kept in a dessicator for 7 days. For SEM analysis, the surfaces of the dentin discs were covered with gold and evaluated by scanning electron microscopy (DSM 960; Carl Zeiss Inc., Oberkochen, BW, Germany). Two independent experiments were performed to ensure the reproducibility of data.

\section{Results}

\section{Microtensile Bond Strength (uTBS)}

The means and standard deviations of the $\mu$ TBS tests are shown in Table 2. The SU:ER/wet, SU:ER/dry and ASB:ER/ PC groups showed bond strength values significantly higher than those of the other groups, with no significant difference among them ( $p>0.05)$. No significant difference between SU:SE/dry and CSB:SE/PC or between SU:SE/ dry and SU:SE/wet was observed ( $p>0.05)$; however, a significant difference occurred between CSB:SE/PC and $\mathrm{SU}: \mathrm{SE} /$ wet groups $(\mathrm{p}<0.05)$. Regarding the fracture analysis

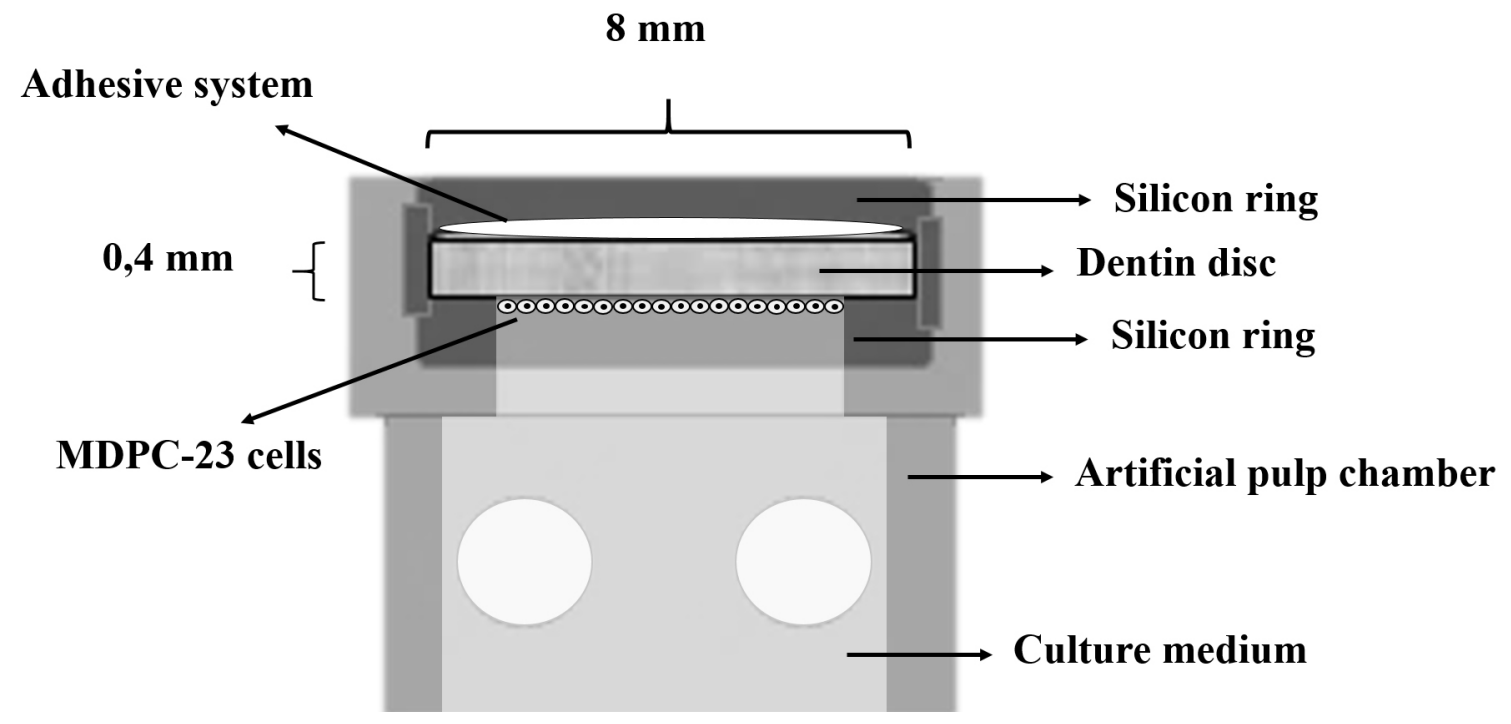

Figure 1. Schematic image of the artificial pulp chamber (APC). Dentin disc was adapted to the APC, remaining between two silicon o'rings. MDPC cells were seeded onto the pulpal side of dentin, which was maintained in direct contact with culture medium. The occlusal surface of the disc was exposed to receive the adhesive systems. 
(Fig. 2), Type IV fracture predominated for the groups subjected to the ER technique; however, Type III fracture predominated for the groups subjected to the SE technique.

\section{Transdentinal Cytotoxicity}

Regarding the cell viability assay, a significant reduction in MDPC-23 viability (about 88\%) was observed for all the experimental groups relative to the NC group $(p<0.05)$, with no significant difference among them ( $p>0.05$ ) (Table 3 ). SEM analysis revealed intense reduction in the numbers of cells that still adhered to dentin surfaces for the groups exposed to the adhesive systems in comparison with the NC group. The MDPC-23 cells that still adhered to dentin exhibited severe morphological changes, characterized mainly by contraction of the cytoplasm and loss of their cytoplasmic processes (Fig. 3).

\section{Discussion}

Universal adhesives are versatile systems in which both SE and ER strategies can be applied to wet or dry dentin with no loss of bonding efficacy (1). Since application

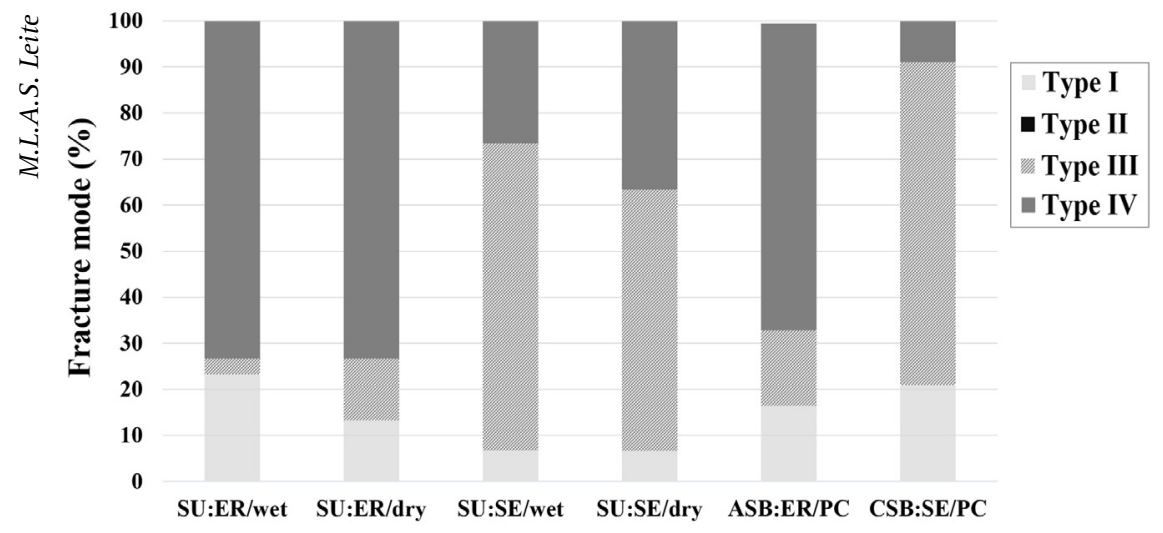

Figure 2. Distribution of the specimens according to fracture mode. protocols of adhesive systems on dentin substrate and dentin humidity play a significant role in the mechanical and biological behavior of the adhesive interface $(2,10)$, in the present study we investigated the microtensile bond strength and transdentinal cytotoxicity of the universal adhesive system Scotchbond ${ }^{\mathrm{TM}}$ Universal (SU; 3M ESPE) applied to wet or dry dentin and following ER or SE bonding techniques. According to our results, the application of SU to both wet and dry dentin surfaces by the ER technique resulted in the highest immediate $\mu$ TBS values, with no significant difference relative to the conventional ER adhesive system Adper ${ }^{\mathrm{TM}}$ Single Bond 2 (ASB; 3M ESPE). In vitro studies also revealed that $S U$ featured statistically similar $\mu$ TBS when applied to dry or wet dentin by the ER mode, even after 1 year of in vitro storage in artificial saliva $(13,14)$. In addition, results of clinical studies showed no significant difference in the performance of ER technique with SU on dry and wet dentin, since the authors found similar marginal adaptation and discoloration up to 36 months $(1,15)$. According to the manufacturers, SU contains an ethanol-/water-based solvent system at 10 to $15 \% \mathrm{w} / \mathrm{v}$ (3M Data Sheet, 2016). This water content is believed to be able to promote re-expansion of collapsed collagen, allowing for infiltration of resin monomers into interfibrillar spaces on air-dried dentin (3). To achieve reliable bonding strength on air-dried dentin, the active application of adhesive systems is a critical step that allows monomers to diffuse through collagen fibrils (16). Therefore, one can speculate that the active application of SU performed in the present investigation may have had a positive effect on the $\mu$ TBS

Table 2. Microtensile bond strength (MPa) results for each experimental group

\begin{tabular}{lccccccc}
\hline & SU:ER/wet & SU:ER/dry & SU:SE/wet & SU:SE/dry & ASB:ER/PC & CSB:SE/PC \\
\cline { 2 - 6 } mTBS (MPa) & $51.33 \pm 8.77^{*} \mathrm{a}^{* *}$ & $51.97 \pm 9.37 \mathrm{a}$ & $9.7 \pm 0.97 \mathrm{~b}$ & $16.8 \pm 4.43 \mathrm{~b}$ & $51.19 \pm 3.72 \mathrm{a}$ & $22.3 \pm 8.00 \mathrm{~b}$ \\
\hline
\end{tabular}

*Values represents mean \pm standard deviation $(\mathrm{n}=5)$. ${ }^{* *}$ Different letters indicates statistically significant differences among groups (ANOVA/ Tukey; $\mathrm{p}<0.05)$.

Table 3. Cell viability percentage of each experimental group obtained by the Alamar Blue assay

\begin{tabular}{|c|c|c|c|c|c|c|c|}
\hline \multirow{2}{*}{$\begin{array}{l}\text { Cell viability } \\
\text { percentage }\end{array}$} & SU:ER/wet & SU:ER/dry & SU:SE/wet & SU:SE/dry & ASB:ER/PC & $\mathrm{CSB}: \mathrm{SE} / \mathrm{PC}$ & $\mathrm{NC}$ \\
\hline & $11.59 \pm 0.6^{*} \mathrm{~b}^{* * *}$ & $11.63 \pm 0.65 b$ & $11.57 \pm 0.51 \mathrm{~b}$ & $11.98 \pm 0.58 \mathrm{~b}$ & $11.74 \pm 0.59 \mathrm{~b}$ & $11.80 \pm 0.73 \mathrm{~b}$ & $100.00 \pm 16.0 \mathrm{a}$ \\
\hline
\end{tabular}

*Values represents mean \pm standard deviation $(\mathrm{n}=8)$. ** Different letters indicates statistically significant differences among groups (ANOVA/ Tukey; $\mathrm{p}<0.05$ ). 
data observed for dry dentin. Additionally, previous studies showed that 10-MDP monomer found in SU composition is responsible for chemical bonding of the adhesive with dentin, allowing for the creation of stable interfaces even without micromechanical retention (17). It has also been shown that $\mathrm{R}_{-} \mathrm{PO}_{4}{ }^{3-}$ of the $10-\mathrm{MDP}$ monomer and $\mathrm{R}-\mathrm{COO}^{-}$of the polyalkenoate copolymer present in the $\mathrm{SU}$ composition reacts with the $\mathrm{Ca}^{2+}$ of hydroxyapatite crystals, creating hydrolytically stable calcium salts, termed 'hydroxyapatite nano-layering' (17). In terms of the SE strategy, no significant difference in $\mu$ TBS was observed between wet and dry dentin. It was also observed that SE bonding featured significantly lower bond strength values than did ER for all tested application protocols, as previously shown (13). Therefore, the null hypothesis of this study was rejected for $\mu$ TBS analysis, since the application protocol played a significant role in the bonding performance of SU to dentin.

When SU is used following the SE strategy, it can be categorized as a one-step SE adhesive system. In clinical studies, one-step SE adhesive systems showed the worst results concerning retention and marginal adaptation compared with two-step SE, two-step ER and three-step ER adhesive systems (18). The $\mathrm{pH}$ of SE adhesive systems plays a role in bond strength to dentin. SU has a relatively high $\mathrm{pH}$ (2.7), being considered as an ultra-mild system, which has been shown to increase retention rates (19). A recent randomized clinical trial showed no significant difference when SU was applied to wet/dry dentin as ER or SE on non-carious cervical lesions, in terms of overall retention, marginal adaptation and staining after 36 months of clinical usage; however, when SU was used as an SE system with no selective etching of enamel, a significant difference was observed when baseline and 36-month evaluation periods were compared (15). In the present study, the negative performance of SU in the SE mode may have been influenced by the absence of enamel margin at the restoration.

It is known that the high hydrophilicity of one-step SE adhesive systems allows for fluid transudation through the dentin-resin interface, thus creating a semi-permeable membrane. This phenomenon increases water sorption and adhesive monomer phase separation, as well as increasing hydrolytic degradation at the resin-dentin interface (20). Therefore, maintaining moist dentin in the SE technique could exceed the amount of water incorporated into the adhesive interface, lowering the concentration of monomers to a threshold that would compromise the bond strength. Also, the smear layer is considered a physical barrier for monomer infiltration to obtain an integrated hybrid layer (21). Regarding the analysis of the fracture mode, most fractures involved the hybrid layer and/or the adhesive layer, as observed in previous studies $(13,14)$. This suggests that hybrid layer was effectively formed after application of adhesive systems in all experimental conditions; nevertheless, concentration of tensions at this interface lead to fracture (22).

Despite the mechanical properties of adhesive systems be considered crucial for adhesive technique selection, the application of resinous dental materials to deep dentin is considered a challenge, since the diffusion of unreacted resin monomers through dentin tubules, which is inherent to
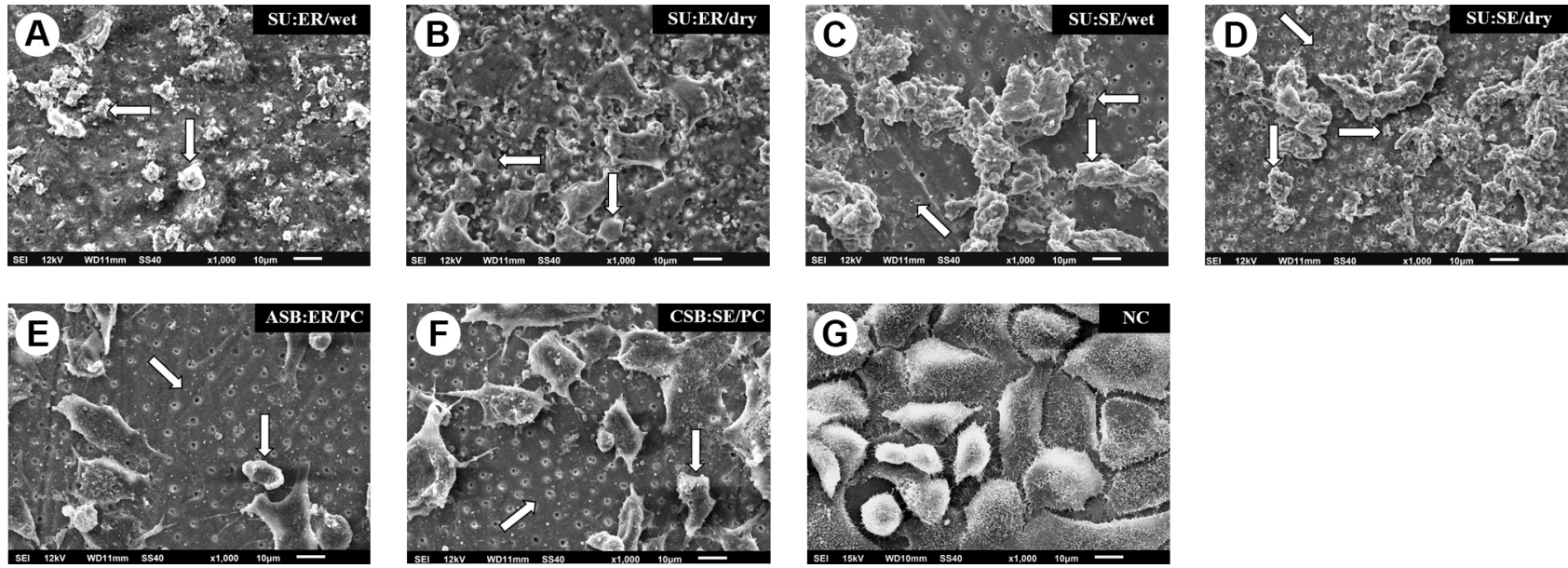

Figure 3. SEM 1,000. Set of images representative of MDPC-23 cells seeded onto dentin for the experimental and control groups. (A-F) Experimental Groups: When the adhesive systems were applied to the occlusal surfaces of dentin discs, a high number of damaged cells detached from the pulpal side of this tubular substrate, exposing large areas of dentin (oblique arrows). Fragments of dead cells can also be seen on dentin surfaces (horizontal arrows). Those few MDPC-23 cells that remained attached to dentin exhibited intense morphological alterations, mainly characterized by reduced size and the loss of cytoplasmic processes (vertical arrows). (G) Control Group: Typical MDPC-23 cells exhibiting an intact flat and wide cytoplasmic membrane with a number of small thin cytoplasmic processes. These cells cover almost the entire dentin substrate. 
the adhesive technique performed on wet dentin substrate, may cause intense and irreversible toxic effects on pulp tissue (5). Deep dentin is a highly permeable substrate, since the diameters and numbers of dentinal tubules per area increase near the pulp chamber (5). High dentin humidity, mainly due to the high outward dentinal fluid movement, can also be found, which definitively interferes with monomer-to-polymer conversion $(2,10)$. Therefore, the high number of unreacted free monomers on deep dentin, even after hybrid layer formation, may induce oxidative stress, inflammatory mediator over-expression, depletion of anti-oxidant enzymes and alteration of dental pulp cell phenotypes. Consequently, apoptosis and necrotic cell death, as well as impaired regenerative potential, can be observed in pulp cells exposed to resin monomers (23).

In the present investigation, the transdentinal cytotoxicity of SU was evaluated by seeding odontoblastlike cells at the pulpal side of $0.4 \mathrm{~mm}$ thick dentin discs adapted to artificial pulp chambers, and applying adhesive systems following clinical protocols to occlusal surface. All discs had their hydraulic conductance measured to standardize the permeability of this tubular substrate for all groups $(4,11)$. This method was used to simulate clinical $\approx$ situation on laboratory condition. Based on the results and according to ISO 10993-5: 2009 (E) (24) recommendations, all adhesive systems assessed in this study caused severe cytotoxic effects to the MDPC-23 cells. In this study, about $88 \%$ of cell viability reduction was observed for the adhesive systems compared with negative control, regardless of application protocol, dentin humidity and composition of adhesive systems. Nevertheless, the null hypothesis was accepted regarding the biological analysis, because no significant differences in cell parameters were found among the groups exposed to SU. We also observed nearly complete destruction of the cell layer on SEM analysis, confirming the severe cytotoxicity of the adhesive systems (24), characterized by reduction in the numbers of cells that remained attached to dentin. These cells, organized in clusters on dentin, were small and rounded, with only a few short cytoplasmic processes on their membrane.

In a previous study carried out by Lanza et al. (4), the same experimental APC/disc design with MDPC-23 seeded on the pulpal sides of $0.4 \mathrm{~mm}$ dentin discs was used. The authors observed that CSB and ASB caused $47.8 \%$ and $53.1 \%$ reductions in MDPC-23 cell viability, respectively, with significant differences being observed between these two materials. The higher cytotoxicity observed in the present investigation may be attributed to the application protocol of the adhesives on dentin surfaces, i.e., two layers of the adhesive systems were applied under active pressure, which has been shown to increase bonding performance $(1,25)$. Conversely, the experiment performed by Lanza et al. (4) involved passive application of a single layer of adhesive systems. Additionally, previous histopathological studies demonstrated that ASB applied following the ER protocol on the pulpal floors of deep cavities prepared in sound human premolars caused intense toxic effects on pulp tissue, characterized by irreversible chronic inflammation associated with resin monomer diffusion through dentinal tubules $(5,10)$. In contrast, when CSB was applied in the same clinical situation according to the SE protocol, a small number of diffusing resin monomers was found inside dentinal tubules, associated with a less intense inflammatory reaction (5). In these in vivo studies, one single layer of the adhesive systems was passively applied to dentin surfaces. Therefore, one can speculate that active application of consecutive layers of SE and ER adhesive systems to very deep dentin may increase the toxic potential of these resinous materials to pulp cells, since the diffusion of uncured resin monomers into dentin structure is enhanced (25). Despite the results obtained in laboratorial studies cannot be directly extrapolated to clinical situation, one may assume that the reduction of $50-90 \%$ in the pulp cells viability mediated by adhesive systems applied to thin dentin discs indicates the possible risk of dental pulp damage caused by these resinous materials after applying them in very deep cavities.

The intense cytotoxicity observed in the present investigation may be attributed to the transdentinal diffusion of hydrophilic monomers such as HEMA, which is the main component of all the adhesive systems tested. Lanza et al. (4) identified HEMA in the culture medium in contact with MDPC-23 cells $24 \mathrm{~h}$ after the application of ASB and CSB to the occlusal sides of dentin discs. Studies have also demonstrated that HEMA is the main resin monomer capable of diffusing through dentin (23), since this monomer is responsible for promoting resin infiltration in deep demineralized dentin (9). It has been shown that this low-molecular-weight monomer is highly cytotoxic, causing pulp cell death mediated by oxidative stress and inhibiting cell phenotype expression related to healing (23). Histopathological studies, in which biocompatible liners such as calcium hydroxide and glass ionomer cements were applied in deep cavities prepared in human teeth, demonstrated that both materials prevent the diffusion of resin monomers from adhesive systems through dentin tubules, with no inflammatory reaction being observed in the subjacent pulp tissue $(5,10)$. Thus, the use of liners with suitable biological properties should be recommended prior application of adhesive systems in deep dentin to avoid pulp tissue damage (10).

Given the limited data obtained in laboratory investigations and the interesting results observed in this in vitro study, along with scientific data from clinical and 
histopathological analyses of human teeth $(5,10)$, we suggest that the application of the universal adhesive Scotchbond ${ }^{\mathrm{TM}}$ Universal (3M ESPE) as well as the other adhesive systems evaluated in the present study should not be recommended for deep dentin due to their high toxic potential to pulp cells, regardless of application protocol on dentin surface and dentin humidity. Nevertheless, the wettability of dentin had no effect on the immediate performance of universal adhesive Scotchbond ${ }^{\mathrm{TM}}$ Universal (3M ESPE); instead, bond strength was negatively influenced by the SE protocol.

\section{Resumo}

Este estudo avaliou o protocolo de aplicação (convencional/ER e autocondicionante/SE) e o grau de umidade da dentina (úmida e seca) sobre a resistência de união à microtração ( $\mu$ TBS) e a citotoxicidade transdentinária do sistema adesivo Scotchbond ${ }^{\mathrm{TM}}$ Universal (SU). Os valores de $\mu$ TBS e o modo de fratura foram registrados $24 \mathrm{~h}$ após aplicação do sistema adesivo e restauração com resina composta pela técnica incremental. Para avaliação da citotoxicidade transdentinária, células odontoblastóides MDPC-23 foram semeadas na face pulpar de discos de dentina $(0,4 \mathrm{~mm}$ de espessura) adaptados a câmaras pulpares artificiais $(\mathrm{n}=8)$. 0 sistema adesivo foi aplicado na superficie oclusal, seguido de incubação por $24 \mathrm{~h}$. A viabilidade e morfologia celular foram avaliadas pelo teste de Alamar Blue e MEV, respectivamente. Adper Single Bond 2 e Clearfil SE Bond foram utilizados como controle positivo do protocolo de aplicação ER e SE, respectivamente. Nenhum tratamento foi realizado no grupo controle negativo (NC). Os dados foram analisados pelos testes de ANOVA e Tukey $(\alpha=5 \%)$. Maiores valores de $\mu$ TBS foram encontrados para o modo ER em comparação com o protocolo $S E(p<0,05)$. 0 grau de umidade da dentina não apresentou efeito na resistência de união do $\mathrm{SU}$ em ambos os protocolos ER e SE ( $p>0.05)$. A maioria das fraturas envolveu a camada híbrida e / ou camada adesiva. Ambas as variáveis não preveniram o intenso efeito citotóxico dos sistemas adesivos sobre as células MDPC-23 em cultura, uma vez que redução intensa na viabilidade celular ( $\pm 88 \%)$ e alterações severas na morfologia celular foram observadas para todos os grupos quando comparados ao NC, sem diferenças entre eles ( $p>0.05)$. Desta forma, foi concluído que a aplicação do SU seguindo o protocolo ER apresentou melhor performance adesiva. No entanto, esse sistema adesivo promoveu intensa citotoxicidade transdentinária sobre células pulpares, independente do protocolo de aplicação e grau de umidade dentinária.

\section{Acknowledgements}

The authors would like to acknowledge the partial financial support from the National Council for Scientific and Technological Development - CNPq (Grants: 443153/2014-4 and 303599/2014-6).

\section{References}

1. Perdigão J, Kose $C$, Mena-Serrano AP, De Paula EA, Tay LY, Reis A, et al.. A new universal simplified adhesive: 18- month clinical evolution. Oper Dent 2014;39:113-127.

2. Tjäderhane L. Dentin bonding: can we make it last? Oper Dent 2015;40:4-18.

3. Pashley DH, Tay FR, Carvalho RM, Rueggeberg FA, Agee KA, Carrilho $\mathrm{M}$, et al.. From dry bonding to water-wet bonding to ethanol-wet bonding. A review of the interactions between dentin matrix and solvated resins using a macromodel of the hybrid layer. Am J Dent 2007;20:7-20

4. Lanza CR, de Souza Costa CA, Furlan M, Alecio A, Hebling J. Transdentinal diffusion and cytotoxicity of self-etching adhesive systems. Cell Biol Toxicol 2009;25:533-543.

5. de Souza Costa CA, Hebling J, Scheffel DL, Soares DG, Basso FG,
Ribeiro AP. Methods to evaluate and strategies to improve the biocompatibility of dental materials and operative techniques. Dent Mater 2014;30:769-784.

6. Zhou J, Chiba A, Scheffel DL, Hebling J, Agee K, Tagami J, et al.. Crosslinked dry bonding: A new etch-and-rinse technique. Dent Mater 2016;32:1124-1132.

7. Reis A, Pellizzaro A, Dal-Bianco K, Gones OM, Patzlaff R, Loguercio AD. Impact of adhesive application to wet and dry dentin on long-term resin-dentin bond strengths. Oper Dent 2007;32:380-387.

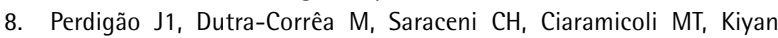
$\mathrm{VH}$, Queiroz CS. Randomized clinical trial of four adhesion strategies: 18-month results. Oper Dent 2012;37:3-11.

9. Abedin F, Ye Q, Good HJ, Parthasarathy R, Spencer P. Polymerizationand solvent-induced phase separation in hydrophilic-rich dentin adhesive mimic. Acta Biomater 2014;10:3038-3047.

10. Soares DG, Basso FG, Scheffel DL, Giro EM, de Souza Costa CA, Hebling J. Biocompatibility of a restorative resin-modified glass ionomer cement applied in very deep cavities prepared in human teeth. Gen Dent 2016;64:33-40.

11. Soares DG, Brito CA, Tavares da Silva RH, Ribeiro AP, Hebling J, Souza Costa CA. Cytocompatibility of HEMA-free resin-based luting cements according to application protocols on dentine surfaces. Int Endod J 2016;49:551-560.

12. Scheffel DL, Soares DG, Basso FG, Souza Costa CA, Pashley D, Hebling J. Transdentinal cytotoxicity of glutaraldehyde on odontoblast-like cells. J Dent. 2015;43:997-1006.

13. Muñoz $M A$, Luque $I$, Hass $V$, Reis $A$, Loguercio $A D$, Bombarda NH. Immediate bonding properties of universal adhesives to dentine. J Dent 2013;41:404-411.

14. Marchesi G, Frassetto $A$, Mazzoni $A$, Apolonio F, Diolosà $M$, Cadenaro $M$, et al.. Adhesive performance of a multi-mode adhesive system: 1-year in vitro study. J Dent 2014;42:603-612.

15. Loguercio $A D$, de Paula EA, Hass V, Luque-Martinez I, Reis $A$, Perdigão J. A new universal simplified adhesive: $36-$ Month randomized doubleblind clinical trial. J Dent 2015;43:1083-1092.

16. Reis A, Chibinski AC, Stanislawczuk R, Wambier DS, Grande RH, Loguercio AD. The role of dentin moisture in the degradation of resindentin interfaces under clinical and laboratory conditions. J Am Dent Assoc 2012;143:e29-e36

17. Yoshihara K, Yoshida Y, Nagaoka N, Hayakawa S, Okihara T, De Munck $J$, et al.. Adhesive interfacial interaction affected by different carbonchain monomers. Dent Mater 2013;29:888-897.

18. Heintze SD1, Ruffieux C, Rousson V. Clinical performance of cervical restorations--a meta-analysis. Dent Mater 2010;26:993-1000.

19. Van Meerbeek B, Yoshihara K, Yoshida Y, Mine A, De Munck J, Van Landuyt KL. State of the art of self-etch adhesives. Dent Mater 2011;27(1):17-28.

20. Tay FR, Frankenberger R, Krejci I, Bouillaguet S, Pashley DH, Carvalho $\mathrm{RM}$, et al.. Single-bottle adhesives behave as permeable membranes after polymerization. I. In vivo evidence. J Dent 2004;32:611-621.

21. Perdigão J1, Reis A, Loguercio AD. Dentin adhesion and MMPs: a comprehensive review. J Esthet Restor Dent 2013;25:219-241.

22. Ausiello $P, A$ Aicella A, Davidson CL. Effect of adhesive layer properties on stress distribution in composite restorations-a $3 D$ finite element analysis. Dent Mater 2002;18:295-303.

23. Botsali MS, Kusgöz A, Altintas SH, Ülker HE, Tanriver M, Kiliç $S$, et al.. Residual HEMA and TEGDMA release and cytotoxicity evaluation of resin-modified glass ionomer cement and compomers cured with different light sources. ScientificWorldJournal 2014;28:2-18.

24. International Standard. Biological evaluation of medical devices - Part 5: Tests for in vitro cytotoxicity. ISO 10993-5:2009 (E). 3th ed. 2009. $34 \mathrm{p}$.

25. Loguercio AD, Muñoz MA, Luque-Martinez I, Hass V, Reis A, Perdigão J. Does active application of universal adhesives to enamel in self-etch mode improve their performance? J Dent 2015;43:1060-1070. 